\title{
Manajemen Guru Dalam Meningkatkan Mutu Pembelajaran
}

\author{
Neny Sulviana ${ }^{1}$, Happy Fitria ${ }^{2}$, Achmad Wahidy ${ }^{3}$ \\ 1,2,3 Program Studi Manajemen Pendidikan, Universitas PGRI Palembang \\ E-mail: neny.sulviana@gmail.com
}

\section{Info Artikel}

Sejarah Artikel:

Diterima (Februari) (2021)

Disetujui (Maret) (2021)

Dipublikasikan (Maret) (2021)

\begin{tabular}{l}
\hline Kata kunci \\
Manajemen Guru; \\
Mengajar; Mutu \\
Pembelajaran \\
Keywords: \\
Teachers Management, \\
Theacing; Learning \\
Quality
\end{tabular}

\begin{abstract}
ABSTRAK
Penelitian ini bertujuan untuk mendeskripsikan manajemen guru mengajar dalam memperbaiki mutu pembelajaran di SMA Negeri 4 Prabumulih, kendala yang dihadapi, dan strategi yang diterapkan guru mengajar. Metode penelitian ini adalah metode kualitatif dengan pendekatan deskriptif. Sumber data penelitian ini kepala sekolah dan guru-guru. Teknik pengumpulan data: (1) observasi; (2) wawancara; (3) dokumentasi. Hasil penelitian ini menyimpulkan bahwa: (1) Manajemen guru mengajar dalam memperbaiki mutu pembelajaran di SMA Negeri 4 Prabumulih dapat dikatakan baik. Guru dalam merencanakan pembelajaran mengacu kepada kurikulum 2013 yang ditetapkan. Guru dalam melaksanakan pembelajaran disusun berdasarkan kalender akademik 2020/2021 yang terdiri dari kegiatan minggu efektif, per semester (semester ganjil dan semester genap); (2) Kendala yang dihadapi adalah keterbatasannya sarana prasarana yang ada di SMA Negeri 4 Prabumulih yaitu infocus, buku pegangan guru dan buku pegangan siswa, alat peraga sebagai media pembelajaran, komputer yang ada di laboratorium; (3) strategi yang diterapkan guru mengajar guna untuk memperbaiki mutu pembelajaran di SMA Negeri 4 Prabumulih, dijelaskan sebagai berikut. yaitu menggunakan buku elektronik dalam menyampaikan pembelajaran, guru-guru menerapkan literasi digital sebagai pengganti terbatasnya sarana yang ada seperti infocus, buku pegangan guru, alat peraga sebagai media pembelajaran, guru dalam menyampaikan materi pembelajaran memvariasikan metode-metode pembelajaran yang ada, sehingga dapat terciptanya suasana belajar yang aktif, kreatif dan menyenangkan.
\end{abstract}




\section{PENDAHULUAN}

Keberhasilan sebuah proses pembelajaran dalam pendidikan di sekolah dipengaruhi oleh banyak hal, salah satunya adalah guru. Guru merupakan komponen utama pengajaran yang memegang peranan penting karena proses belajar mengajar di kelas dapat berjalan dengan baik sangat ditentukan oleh faktor guru.

Guru memiliki tugas menyampaikan materi pelajaran kepada siswa melalui interaksi komunikasi dalam proses belajar mengajar, dimana keberhasilan guru dalam menyampaikan materi sangat tergantung pada kelancaran interaksi komunikasi yang berpengaruh terhadap pesan yang diberikan oleh guru ( Hamid, 2010: 43). Faktor lainnya yang juga menentukan hasil belajar siswa adalah sekolah. Semakin tinggi kemampuan belajar siswa dan kualitas pengajaran di sekolah maka semakin tinggi pula hasil belajar siswa (Wasliman, 2012: 159). Seorang guru memiliki tanggung jawab moral kepada masyarakat bahwa ia menjalankan tugasnya dengan usaha, kejujuran dan keikhlasan yang tidak bisa ditawar. Dari sini kita dapat memahami bahwa hanya berbekal ilmu saja tidak cukup untuk bisa menyebut diri kita guru.

Pendidikan pada umumnya ditujukan untuk mengembangkan potensi siswa. Sebagai seorang guru yang baik, secara alami dia menginginkan sebanyak mungkin siswa untuk lulus atau mendapatkan nilai yang baik. Guru akan merasa kecewa sekali jika banyak dari siswanya menurun nilainya atau bahkan gagal. Dalam hal ini, guru diharapkan dapat meningkatkan potensi siswanya dan harus bijak dalam membatasi keinginannya untuk memiliki siswa yang memiliki nilai tinggi (Sukardi, 2016: 11). Susanto (2016: 13), menjelaskan bahwa guru merupakan komponen yang sangat menentukan dalam pelaksanaan strategi pembelajaran. Berdasarkan pendapat tersebut, dapat ditekankan bahwa salah satu faktor eksternal yang sangat mempengaruhi hasil belajar siswa adalah guru.

Dalam proses pembelajaran guru memegang peranan yang sangat penting. Peran guru khususnya bagi siswa usia sekolah dasar tidak mungkin tergantikan oleh perangkat lain seperti televisi, radio dan komputer. Karena siswa merupakan makhluk yang membutuhkan bimbingan dan bantuan orang dewasa dalam proses pengembangan dirinya. Dikarenakan guru merupakan salah satu unsur terpenting dalam pendidikan, maka mutu pendidikan sangat ditentukan oleh standar mutu guru. Oleh karenanya guru perlu meningkatkan kompetensi dirinya sebagaimana tertuang dalam Undang-Undang Nomor 14 Tahun 2005 tentang Guru dan Dosen. 
Ada beberapa kompetensi yang harus dipenuhi guru antara lain: kompetensi pedagogik, kepribadian, kompetensi profesional dan kompetensi sosial. Untuk menjawab pertanyaan tentang apakah standar kompetensi guru di Indonesia sudah memenuhi keempat kompetensi di atas, tentunya harus ada langkah konkrit untuk meningkatkan kualitas dan kompetensi guru. Pihak terkait dalam hal ini Kementerian Pendidikan dan Kebudayaan menyadari hal itu dan mengantisipasinya dengan memetakan standar kompetensi guru di Indonesia. Berbagai pelatihan dan pendidikan untuk meningkatkan kompetensi guru telah dilakukan, termasuk pelatihan dan pendidikan pengajaran yang disesuaikan dengan era revolusi industri 4.0 saat ini.

Guru harus berkualitas menurut standar tertentu (Rusman, 2011:79). Dalam rangka pelaksanaan tugas keprofesionalan seorang guru atau pendidik terdapat tantangan normatif berupa sertifikasi guru sebagai jaminan lulus uji kompetensi sebagai guru profesional dengan memenuhi standar yang telah ditentukan. Sertifikasi pendidik merupakan pemberian sertifikat profesi sebagai bukti profesionalisme guru dalam melaksanakan tugasnya. Ada tiga kriteria guru yang profesional yang menjadi syarat untuk sampai kepada maksud tersebut, yakni: (1) guru yang profesional adalah yang telah memenuhi kompetensi dan keahlian inti sebagai pendidik); (2) guru yang profesional hendaknya membangun kesejawatan; (3) guru yang profesional hendaknya mampu merawat jiwa sosialnya. Pendidik harus memiliki kualifikasi akademik yang dibuktikan dengan ijazah dan/atau sertifikat keahlian yang sesuai ketentuan yang berlaku. Selain itu dengan perubahan zaman guru harus mampu menghadirkan pembelajaran abad 21 yang mendorong siswa untuk berpikir kritis, kreatif, inovatif, komunikatif, dan mampu berkolaborasi.

Menjadi seorang guru berarti tidak boleh berhenti belajar dan mengembangkan diri. Bersama rekan sejawat dalam organisasi seperti MGMP atau KKG guru harus terus belajar untuk mengembangkan semua potensi dalam dirinya, dan meningkatkan kecakapan agar dapat menyesuaikan dengan perkembangan zaman. Karena guru adalah pejuang pendidikan yang memiliki peran, tugas dan tanggung jawab mulia sebagai panggilan jiwa di garda terdepan dalam mencerdaskan kehidupan bangsa. Tugas seorang guru tidak hanya melaksanakan pembelajaran dari tumpukan teori dan pengetahuan serta doktrin tetapi harus mampu melaksanakan pembelajaran yang merangsang aktivitas dan potensi siswa sesuai dengan kapasitasnya masing-masing. Tugas utama seorang guru adalah mendidik yang artinya guru tidak hanya berbagi ilmu dengan siswa tetapi mendidik siswa dari segi sikap dan tindakan (Rizaldi, 2014: 78). 
Usaha untuk meningkatkan kualitas guru telah dilakukan oleh pemerintah dengan berbagai cara, antara lain dengan memberikan block grant kepada sekolah sebagai dana stimulan untuk pelaksanaan program pengembangan keprofesian guru, pembentukan himpunan guru mata pelajaran, pembentukan organisasi forum ilmiah guru, dan penerbitan jurnal ilmiah untuk guru. Selain itu juga memberdayakan Program Musyawarah Guru Mata Pelajaran (MGMP) yang sudah ada di hampir setiap kabupaten / kota. Berbagai program pengembangan kualitas guru terutama bertujuan untuk meningkatkan kemampuan dan keterampilan guru dalam merencanakan, mengembangkan, melaksanakan, dan mengawasi proses pembelajaran untuk mendukung peningkatan mutu pendidikan di setiap satuan sekolah (Sumardin, 2016: 2).

Pengelolaan kelas merupakan aspek pendidikan yang seringkali menjadi perhatian utama para calon guru, guru baru, bahkan guru berpengalaman yang menginginkan siswanya belajar secara maksimal. Penciptaan harapan seperti itu adalah studi tentang manajemen kelas. Menurut Djamarah dan Zain (2010: 173). Manajemen kelas adalah masalah perilaku yang kompleks, dan guru menggunakannya untuk menciptakan dan memelihara kondisi kelas sedemikian rupa sehingga siswa dapat mencapai tujuan pengajaran secara efisien dan memungkinkan mereka untuk belajar. Pengeloaan kelas adalah kegiatan-kegiatan yang diupayakan oleh guru untuk dapat menciptakan situasi kelas yang kondusif dalam rangka mencapai tujuan pembelajaran yang optimal. Menurut Djamarah dan Zain (2010:173) pengelolaan kelas merupakan masalah tingkah laku yang kompleks, dan guru menggunakannya untuk menciptakan dan mempertahankan kondisi kelas sedemikian rupa sehingga anak didik dapat mencapai tujuan pengajaran secara efesien dan memungkinkan mereka dapat belajar. Dalam penjelasan yang lain Danim (2012:91) bahwa di kelaslah segala aspek pembelajaran bertemu dan berproses. Guru dengan segala kemampuannya, siswa dengan segala latar belakang dan potensinya, kurikulum dengan segala komponennya, metode dengan pendekatannya, media dengan segala peralatannya, materi dengan segala sumber belajarnya bertemu dan berinteraksi di dalam kelas.

Selanjutnya hasil belajar juga ditentukan oleh apa yang terjadi di kelas. Oleh karena itu, sudah selayaknya kelas dalam pengelolaannya dilakukan dengan baik, profesional, berkesinambungan dan berkelanjutan. Hubungan positif antara guru dan siswa hanya terbangun dengan sikap positif. Walaupun terdapat kelemahan pada diri siswa, tentunya banyak keuntungannya dan jauh lebih baik untuk mengembangkan potensi positif pada diri siswa daripada mencari sisi lemahnya (Karawati, 2014: 28). 
Manajemen kelas tidak hanya berupa penataan ruang kelas, fasilitas fisik dan rutinitas. Kegiatan pengelolaan kelas dimaksudkan untuk menciptakan dan memelihara suasana dan kondisi kelas. Sehingga proses belajar mengajar dapat berlangsung secara efektif dan efisien. Misalnya, memberikan penguatan, membina hubungan guru-murid dan membuat aturan kelompok yang produktif (Karawati, 2014: 32). Manajemen kelas diperlukan karena dari hari ke hari bahkan dari waktu ke waktu tingkah laku dan perbuatan siswa selalu berubah. Kelas selalu dinamis dalam bentuk perilaku, perbuatan, sikap, mental, dan emosional siswa (Nurdin, 2012:39).

Danim (2012:189) menjelaskan bahwa kinerja manajemen kelas yang efektif tercermin dari keberhasilan guru dalam menciptakan lingkungan belajar secara positif dan memberdayakan siswa untuk memahami dan menjadi efektif dalam melibatkan diri pada proses pengelolaan kelas. Dalam kegiatan belajar mengajar, guru menjadi pusat perhatian dan bertanggung jawab untuk mengarahkan dan membimbing siswa dalam setiap proses pembelajaran yang berlangsung. Usman (2012: 10) sebagai pengelola kelas, guru bertanggung jawab menjaga lingkungan fisik kelas agar selalu menyenangkan dalam belajar dan membimbing proses intelektual dan sosial di dalam kelas. Dengan demikian guru tidak hanya mendorong siswa untuk belajar, tetapi juga menumbuhkan karakter bekerja sama dengan siswa lainnya. Kegiatan pembelajaran yang berhasil tidak saja menuntut guru memiliki kemampuan menguasai materi pelajaran, strategi dan metode mengajar, menggunakan media atau alat pembelajaran. Akan tetapi guru juga harus mampu menciptakan situasi dan kondisi belajar yang kondusif serta menyenangkan yang hanya dapat terwujud jika guru mampu mengatur suasana pembelajaran, mengkondisikan siswa untuk belajar dan memanfaatkan sarana atau media pembelajaran serta dapat mengendalikan suasana yang menyenangkan untuk mencapai tujuan pembelajaran, kemampuan tersebut yang disebut kemampuan mengelola kelas. Kegiatan pengelolaan kelas merupakan suatu kegiatan yang erat hubungannya dengan kegiatan pembelajaran dan sangat penting guna tercapainya proses pembelajaran yang efektif.

Oleh karena itu dalam mengelola kelas seorang guru tentunya perlu memperhatikan bagaimana menciptakan iklim belajar yang tepat, mengatur ruang belajar, dan mengelola kegiatan belajar mengajar sehingga kegiatan belajar mengajar bisa berjalan sesuai dengan tujuan yang sudah ditetapkan. Menurut Wahyuningrum (2013:65), ada tiga kegiatan inti pada pengelolaan kelas, yaitu guru harus menciptakan iklim belajar yang tepat meliputi kehangatan dan keantusiasan, tantangan, bervariasi, keluwesan, penekanan pada hal-hal 
yang positif, dan penanaman disiplin diri, guru harus mengatur ruang belajar meliputi pengaturan tempat duduk peserta didik, pengaturan media pendidikan, pemberian aromaterapi dan guru harus dapat mengelola kegiatan belajar mengajar meliputi keterampilan membuka dan menutup pelajaran, keterampilan menjelaskan, keterampilan bertanya, keterampilan memberi penguatan, keterampilan menggunakan media pembelajaran, keterampilan membimbing diskusi kelompok kecil, keterampilan mengelola kelas, keterampilan mengadakan variasi serta keterampilan mengajar perorangan dan kelompok kecil.

Hasil wawancara awal peneliti dengan Kepala SMA Negeri 4 Prabumulih, disebutkan bahwa selaku pimpinan sekolah, manajemen mutu guru, sekarang ini di SMA Negeri 4 Prabumulih memiliki jumlah tenaga pendidik sebanyak 37 orang guru yang terdiri dari 26 orang guru PNS dan 11 orang guru honorer. Tenaga kependidikan sebanyak 6 orang. Dari 26 orang guru PNS yang sudah memiliki sertifikat pendidik sebanyak 23 orang guru PNS $(88,56 \%)$ dan 3 orang guru PNS $(11,54 \%)$ belum memiliki sertifikat pendidik. SMA Negeri 4 Prabumulih sendiri berdiri sejak tahun 2004 dan belum terakreditasi. Baru pada tahun 2011 SMA Negeri 4 Prabumulih memperoleh nilai akreditasi C. Dengan melakukan pembenahan di berbagai bidang baik, dari segi fisik maupun mutu tenaga pendidik dan prestasi siswa akhirnya diperoleh nilai akreditasi B pada tahun 2015. Dalam hal peningkatan kualitas guru, Kepala Sekolah selalu berupaya untuk memperbaiki kualitas guru dalam mengelola kelas. Namun kendala yang dihadapi adalah fasilitas sarana dan prasarana yang ada di SMA Negeri 4 Prabumulih masih belum memadai, seperti buku-buku yang ada di perpustakaan kurang banyak, buku pegangan guru hanya 1 , seharusnya paling sedikit 2 atau 3 buku pegangan sehingga dapat lebih bermakna pada saat guru menyampaikan proses pembelajaran. Disamping itu juga, sarana media alat peraga sebagai sumber belajar pendukung juga belum memadai, seperti banyak alat peraga saat ini dalam keadaan rusak bahkan tidak ada, seperti infocus, media charta, tabung reaksi, mikroskop, sehingga para guru yang mengelola pembelajaran tidak dapat menyampaikannya secara maksimal kepada peserta didik.

Perubahan kurikulum yang terjadi dari KTSP 2006 menjadi kurikulum 2013 juga menjadi salah satu hal yang mempengaruhi manajemen guru mengajar di kelas. Selain itu perkembangan zaman terutama saat ini revolusi indutri 4.0 menuntut guru harus handal dan profesional terutama dalam pemanfaatan teknologi dalam proses pembelajaran agar mampu menciptakan pembelajaran abad 21 yang aktif, kreatif, inovatif dan menyenangkan. Kepala 
Sekolah juga menambahkan keterangannya bahwa pihak sekolah akan berupaya untuk meningkatkan kemampuan guru dalam mengajar dan dan mengimplementasikan pengajaran dengan menggunakan Kurikulum 2013 dengan membekali para guru melalui kegiatan pendidikan dan pelatihan, workshop atau seminar sehingga dapat diterapkan dalam proses pembelajaran. Dengan manajemen guru mengajar yang baik tentu akan sangat berpengaruh pada mutu pembelajaran di sekolah yang pada akhirnya akan sangat menentukan prestasi dan hasil belajar siswa.

\section{METODE PENELITIAN}

Tempat yang dijadikan kajian penelitian ini adalah di SMA Negeri 4 Prabumulih. Waktu penelitian dilakukan selama tiga bulan, yaitu pada bulan Oktober 2020 sampai dengan Desember 2020. Latar penelitian yang digunakan dalam penelitian ini adalah metode penelitian deskriptif kualitatif. Metode pengumpulan data yang digunakan dalam penelitian ini adalah wawancara, dokumentasi dan observasi. Teknik analisis data menggunakan langkah-langkah analisis pada penelitian kualitatif yaitu, reduksi data, penyajian data, pengambilan kesimpulan dan verifikasi data.

\section{HASIL PENELITIAN}

Berdasarkan hasil temuan penelitian dapat dianalisis sebagai berikut.

\section{Analisis Data Manajemen Guru dalam Memperbaiki Mutu Pembelajaran di SMA Negeri 4 Prabumulih}

Berdasarkan deskripsi data penelitian bahwa manajemen guru mengajar dalam memperbaiki mutu pembelajaran di SMA Negeri 4 Prabumulih dapat dikatakan baik. Guru dalam merencanakan pembelajaran sudah diarahkan oleh kepala sekolah yang mana RPP yang dibuat mengacu kepada kurikulum 2013 yang ditetapkan. Guru dalam melaksanakan pembelajaran dapat dikatakan baik, RPP yang disusun berdasarkan kalender akademik 2020/2021 yang terdiri dari kegiatan minggu efektif, per semester (semester ganjil dan semester genap). Guru dalam mengevaluasi hasil pembelajaran dapat dikatakan baik, karena evaluasi yang dilakukan setiap akhir dari proses pembelajaran baik tengah semester maupun per semester (semester ganjil dan semester genap), guru dalam memberikan tindaklanjut/follow up dapat dikatakan baik, dan guru dalam memberikan penguatan terhadap peserta didik dalam proses pembelajaran dapat dikatakan baik. 
Hal ini dipertegas oleh Kepala SMA Negeri 4 Prabumulih melalui wawancara yang mengatakan:

Persiapan penyusunan RPP di SMA Negeri 4 Prabumulih mengacu kepada kurikulum 2013 sebagaimana yang di instruksikan oleh Kemendikbud R.I tahun 2018 dengan cara merevisi kurikulum yang dirancang pada tahun lalu. Persiapan bahan ajar di SMA Negeri 4 Prabumulih dilakukan melalui rapat dewan guru dan musyawarah kelompok guru per mata pelajaran yang akan di rancang secara bersama-sama yang mengacu kepada kurikulum 2013 sebagaimana yang di instruksikan oleh Kemendikbud R.I tahun 2018 dengan cara merevisi kurikulum yang dirancang pada tahun lalu. Guru dalam menggunakan media pembelajaran dapat dikatakan cukup. Hal ini diakui oleh kepala sekolah bahwa keterbatasan sarana prasarana media pembelajaran yang ada di SMA Negeri 4 Prabumulih. Guru dalam menggunakan Lembar Kerja Peserta Didik (LKPD) di SMA Negeri 4 Prabumulih dapat dikatakan baik, yang memuat kompetensi dasar, indikator pencapaian, materi pembelajaran, aspek penilaian kognitif, apektif, dan psikomotor. Guru dalam mengevaluasi dari hasil pembelajaran yang telah disampaikan dapat dikatakan baik, dimana evaluasi yang telah dilakukan guru sudah mengikuti aturan kalender pendidikan di SMA Negeri 4 Prabumulih yaitu mengevaluasi hasil pembelajaran setiap tengah semester dan per semester (semester ganjil dan semester genap). Guru dalam mengatur fasiltias belajar peserta didik dapat dikatakan baik, dimana fasilitas belajar sebagai pendukung yang ada di SMA Negeri 4 Prabumulih seperti kursi, meja, ruang belajar laboratorium, perpustakaan, sudah memadai.

\section{Analisis Data Kendala yang Dihadapi Guru Mengajar dalam Memperbaiki Mutu Pembelajaran di SMA Negeri 4 Prabumulih}

Berdasarkan deskripsi data penelitian yang telah dikemukakan di atas, dapat dijelaskan bahwa kendala yang dihadapi guru mengajar dalam memperbaiki mutu pembelajaran di SMA Negeri 4 Prabumulih, dijelaskan sebagai berikut. (1) keterbatasannya sarana prasarana yang ada di SMA Negeri 4 Prabumulih yaitu infocus, buku pegangan guru dan buku pegangan siswa, alat peraga sebagai media pembelajaran, komputer yang ada di laboratorium; (2) keterbatasan kemampuan guru dalam penggunaan I.T (khususnya guru dalam menggunakan infocus).; (3) keterbatasan kemampuan guru dalam menggunakan media (guru kurang mampu dalam menyesuaikan media dengan pembelajaran yang disampaikan).

Hal ini dikatakan oleh guru-guru yang mengampu mata pelajaran di SMA Negeri 4 Prabumulih, yang mengatakan:

keterbatasannya sarana prasarana yang ada di SMA Negeri 4 Prabumulih yaitu infocus, buku pegangan guru dan buku pegangan siswa, alat peraga sebagai media pembelajaran, komputer yang ada di laboratorium. Disamping itu, keterbatasan kemampuan guru dalam penggunaan I.T (khususnya guru dalam menggunakan infocus), serta keterbatasan kemampuan guru dalam 
menggunakan media (guru kurang mampu dalam menyesuaikan media dengan pembelajaran yang disampaikan.

\section{Analisis Data Strategi yang Diterapkan Guru Mengajar Guna Untuk Memperbaiki Mutu Pembelajaran di SMA Negeri 4 Prabumulih}

Berdasarkan deskripsi data penelitian yang telah dikemukakan di atas, dapat dijelaskan bahwa strategi guru mengajar dalam memperbaiki mutu pembelajaran di SMA Negeri 4 Prabumulih, dijelaskan sebagai berikut. (1) menggunakan buku elektronik dalam menyampaikan pembelajaran; (2) guru-guru menerapkan literasi digital sebagai pengganti terbatasnya sarana yang ada seperti infocus, buku pegangan guru, alat peraga sebagai media pembelajaran, (3) guru dalam menyampaikan materi pembelajaran memvariasikan metodemetode pembelajaran yang ada, sehingga dapat terciptanya suasana belajar yang aktif, kreatif dan menyenangkan.

Berdasarkan hasil penelitian melalui observasi bahwa manajemen guru mengajar dalam memperbaiki mutu pembelajaran di SMA Negeri 4 Prabumulih, bahwa guru dalam merencanakan pembelajaran sudah diarahkan oleh kepala sekolah yang mana RPP yang dibuat mengacu kepada kurikulum 2013 yang ditetapkan. Guru dalam melaksanakan pembelajaran dapat dikatakan baik, RPP yang disusun berdasarkan kalender akademik 2020/2021 yang terdiri dari kegiatan minggu efektif, per semester (semester ganjil dan semester genap). Guru dalam mengevaluasi hasil pembelajaran dapat dikatakan baik, karena evaluasi yang dilakukan setiap akhir dari proses pembelajaran baik tengah semester maupun per semester (semester ganjil dan semester genap), guru dalam memberikan tindaklanjut/follow up dapat dikatakan baik, dan guru dalam memberikan penguatan terhadap peserta didik dalam proses pembelajaran dapat dikatakan baik.

Selanjutnya strategi yang dilakukan guru dalam memperbaiki mutu pembelajaran di SMA Negeri 4 Prabumulih, yaitu sebagai berikut: (1) menggunakan buku elektronik dalam menyampaikan pembelajaran; (2) guru-guru menerapkan literasi digital sebagai pengganti terbatasnya sarana yang ada seperti infocus, buku pegangan guru, alat peraga sebagai media pembelajaran, (3) guru dalam menyampaikan materi pembelajaran memvariasikan metodemetode pembelajaran yang ada, sehingga dapat terciptanya suasana belajar yang aktif, kreatif dan menyenangkan.

Hal ini dikatakan oleh guru-guru yang ada di SMA Negeri 4 Prabumulih, yang mengatakan:

Guru-guru menggunakan buku elektronik dalam menyampaikan pembelajaran, guru-guru menerapkan literasi digital sebagai pengganti 
terbatasnya sarana yang ada seperti infocus, buku pegangan guru, alat peraga sebagai media pembelajaran, guru-guru dalam menyampaikan materi pembelajaran memvariasikan metode-metode pembelajaran yang ada, sehingga dapat terciptanya suasana belajar yang aktif, kreatif dan menyenangkan.

Selanjutnya hasil penelitian ini di dukung dan diperkuat dengan data dokumentasi yang meliputi: (1) Foto Rencana Perangkat Pembelajaran; (2) Lembar Observasi Manajemen Guru dalam Memperbaiki Mutu Pembelajaran; (3) (4) Instrumen Hasil Supervisi Akademik Penilaian Guru; (5) Instrumen hasil Penilaian oleh Guru; (6) Hasil Wawancara dengan Kepala Sekolah; (7) Hasil Wawancara dengan Guru-Guru; (8) Foto-foto Hasil Observasi, seperti foto kegiatan guru mengajar di kelas, foto Sarana Prasarana; (9) dokumentasi lainnya yang mendukung data penelitian, seperti surat izin penelitian.

\section{PEMBAHASAN}

Berdasarkan hasil temuan penelitian, dibahas sebagai berikut.

\section{Analisis Data Manajemen Guru dalam Memperbaiki Mutu Pembelajaran di SMA Negeri 4 Prabumulih}

Berdasarkan deskripsi data penelitian bahwa manajemen guru mengajar dalam memperbaiki mutu pembelajaran di SMA Negeri 4 Prabumulih dapat dikatakan baik. Guru dalam merencanakan pembelajaran sudah diarahkan oleh kepala sekolah yang mana RPP yang dibuat mengacu kepada kurikulum 2013 yang ditetapkan. Guru dalam melaksanakan pembelajaran dapat dikatakan baik, RPP yang disusun berdasarkan kalender akademik 2020/2021 yang terdiri dari kegiatan minggu efektif, per semester (semester ganjil dan semester genap). Guru dalam mengevaluasi hasil pembelajaran dapat dikatakan baik, karena evaluasi yang dilakukan setiap akhir dari proses pembelajaran baik tengah semester maupun per semester (semester ganjil dan semester genap), guru dalam memberikan tindaklanjut/follow up dapat dikatakan baik, dan guru dalam memberikan penguatan terhadap peserta didik dalam proses pembelajaran dapat dikatakan baik.

\section{Analisis Data Kendala yang Dihadapi Guru Mengajar dalam Memperbaiki Mutu}

\section{Pembelajaran di SMA Negeri 4 Prabumulih}

Berdasarkan deskripsi data penelitian yang telah dikemukakan di atas, dapat dijelaskan bahwa kendala yang dihadapi guru mengajar dalam memperbaiki mutu pembelajaran di SMA Negeri 4 Prabumulih, dijelaskan sebagai berikut. (1) keterbatasannya sarana prasarana yang ada di SMA Negeri 4 Prabumulih yaitu infocus, buku pegangan guru dan buku pegangan siswa, alat peraga sebagai media pembelajaran, komputer yang ada di 
laboratorium; (2) keterbatasan kemampuan guru dalam penggunaan I.T (khususnya guru dalam menggunakan infocus).; (3) keterbatasan kemampuan guru dalam menggunakan media (guru kurang mampu dalam menyesuaikan media dengan pembelajaran yang disampaikan).

\section{Analisis Data Strategi yang Diterapkan Guru Mengajar Guna Untuk Memperbaiki Mutu Pembelajaran di SMA Negeri 4 Prabumulih}

Berdasarkan deskripsi data penelitian yang telah dikemukakan di atas, dapat dijelaskan bahwa strategi yang diterapkan guru mengajar guna untuk memperbaiki mutu pembelajaran di SMA Negeri 4 Prabumulih, dijelaskan sebagai berikut. yaitu sebagai berikut: (1) menggunakan buku elektronik dalam menyampaikan pembelajaran; (2) guruguru menerapkan literasi digital sebagai pengganti terbatasnya sarana yang ada seperti infocus, buku pegangan guru, alat peraga sebagai media pembelajaran, (3) guru dalam menyampaikan materi pembelajaran memvariasikan metode-metode pembelajaran yang ada, sehingga dapat terciptanya suasana belajar yang aktif, kreatif dan menyenangkan.

Berdasarkan hasil penelitian yang telah dikemukakan di atas, penelitian ini di dukung dari beberapa kajian teoretik seperti yang dijelaskan oleh Hamid, (2010:43), bahwa tugas guru adalah menyampaikan materi pelajaran kepada siswa melalui interaksi komunikasi dalam proses belajar mengajar yang dilakukannya keberhasilan guru dalam menyampaikan materi sangat tergantung pada kelancaran interaksi komunikasi membawa akibat terhadap pesan yang diberikan guru.

Menurut Susanto (2016:13) bahwa guru adalah komponen yang sangat menentukan dalam implementasi suatu strategi pembelajaran. Bedasarkan pendapat ini dapat ditegaskan bahwa salah satu factor eksternal yang sangat mempengaruhi hasil belajar siswa adalah guru.

Guru merupakan salah satu unsur terpenting dalam pendidikan. Baik buruknya kualitas pendidikan sangat ditentukan oleh standar kualitas guru. Oleh karena itu, guru perlu meningkatkan kompetensinya seperti tercantum dalam Undang-undang Nomor 14 Tahun 2005 tentang Guru dan Dosen.

Kurniasih (2017:68) menjelaskan bahwa bukti kualitas menurut standar tertentu yang menjamin seseorang dapat dikatakan sebagai guru profesional adalah selembar sertifikat. Pemerolehan sertifikat sebagai guru profesional harus melalui dan lulus uji kompetensi guru.Ada dua kriteria utama yang menjadi syarat untuk sampai kepada maksud tersebut, yakni: (1) Memenuhi kualifikasi akademik pendidikan formal minimum diploma empat (DIV) atau sarjana (S1); (2) Memenuhi standar kompetensi sebagai agen pembelajaran.Pendidik harus memiliki kualifikasi akademik dan kompetensi sebagai agen pembelajaran, sehat 
jasmani dan rohani, serta memiliki kemampuan untuk mewujudkan tujuan pendidikan Nasional. Kualifikasi akademik, sebagaimana yang dimaksudkan adalah tingkat pendidikan minimal yang harus dipenuhi oleh seseorang yang dibuktikan dengan ijazah dan/atau sertifikat keahlian yang relevan sesuai ketentuan perundang-undangan yang berlaku.

Berbagai program pengembangan kualitas guru itu utamanya bertujuan untuk meningkatkan kemampuan dan keterampilan guru dalam merencanakan, mengembangkan, mengimplementasikan dan mensupervisi proses pembelajaran guna mendukung peningkatan mutu pendidikan di setiap unit sekolah (Sumardin, 2016:2). Mutu pembelajaran berdasarkan Peraturan Pemerintah Nomor 19 Tahun 2005 tentang Standar Nasional Pendidikan Bab I Ketentuan Umum sebagai berikut: a) Pasal 1 ayat (18) "Evaluasi pembelajaran adalah kegiatan pengendalian, penjaminan, dan penetapan mutu pembelajaran terhadap berbagai komponen pendidikan pada setiap jalur, jenjang, dan jenis pendidikan sebagai bentuk pertanggungjawaban penyelenggaraan pendidikan". b) Pasal 3 "Standar Nasional Pendidikan berfungsi sebagai dasar dalam perencanaan, pelaksanaan, dan pengawasan pendidikan dalam rangka mewujudkan pendidikan nasional yang bermutu". c) Pasal 4 "Standar Nasional Pendidikan bertujuan menjamin mutu pembelajaran nasional dalam rangka mencerdaskan kehidupan bangsa dan membentuk watak serta peradaban bangsa yang bermartabat".

Sekolah sebagai lembaga sebuah organisasi dalam memperbaiki mutu harus melihat seluruh aspek komponen sekolah. Sehingga seluruh komponen sekolah bertanggungjawab terhadap tugas dan fungsinya masing-masing. Mclaugklin (dalam Rohiat, 2013:41) menjelaskan " Total quality is total in three sense: it cover every process, every job, and every person." Pendidikan nasional yang bermutu diarahkan untuk pengembangan potensi peserta didik agar menjadi manusia yang beriman dan bertakwa kepada Tuhan Yang Maha Esa, berahlak mulia, sehat, berilmu, cakap, kreatif, mandiri, dan menjadi warga negara yang demokratis serta bertanggungjawab. Mutu adalah kemampuan (ability) yang dimiliki oleh suatu produk atau jasa (services) yang dapat memenuhi kebutuhan atau harapan, kepuasan (satisfaaction) pelangga (customers) yang dalam pendidikan dikelompokkan menjadi dua, yaitu internal customer dan eksternal. Internal customer yaitu siswa atau mahasiswa sebagai pembelajar dan eksternal customer yaitu masyarakat dan dunia industri. Mutu tidak berdiri sendiri artinya banyak faktor untuk mencapainya dan untuk memelihara mutu (Nanang, 2016:2). 
Merujuk pada pemikiran Edward Sallis (dalam Hidayat, 2013:91) mengidentifikasi 13 ciri-ciri sekolah bermutu, yaitu: 1). Sekolah berfokus pada pelanggan, baik pelanggan internal maupun eksternal; 2) Sekolah berfokus pada upaya untuk mencegah masalah yang muncul, dengan komitmen untuk bekerja secara benar dari awal; 3) Sekolah memiliki investasi pada sumber daya manusianya, sehingga terhindar dari berbagai "kerusakan psikologis" yang sangat sulit memperbaikinya; 4) Sekolah memiliki strategi untuk mencapai kualitas, baik di tingkat pimpinan, tenaga akademik, maupun tenaga administratif; 5) sekolah mengelola atau memperlakukan keluhan sebagai umpan balik untuk mencapai kualitas dan memposisikan kesalahan sebagai instrumen untuk berbuat benar pada masa berikutnya; 6) Sekolah memiliki kebijakan dalam perencanaan untuk mencapai kualitas, baik untuk jangka pendek, jangka menengah maupun jangka panjang; 7) Sekolah mengupayakan proses perbaikan dengan melibatkan semua orang sesuai dengan tugas pokok, fungsi dan tanggung jawabnya; 8) Sekolah mendorong orang dipandang memiliki kreativitas, mampu menciptakan kualitas dan merangsang yang lainnya agar dapat bekerja secara berkualitas; 9) Sekolah memperjelas peran dan tanggung jawab setiap orang, termasuk kejelasan arah kerja secara vertikal dan horizontal; 10) Sekolah memiliki strategi dan kriteria evaluasi yang jelas; 11) Sekolah memandang atau menempatkan kualitas yang telah dicapai sebagai jalan untuk untuk memperbaiki kualitas layanan lebih lanjut; 12) Sekolah memandang kualitas sebagai bagian integral dari budaya kerja; 13) Sekolah menempatkan peningkatan kualitas secara terus menerus sebagai suatu keharusan.

Berdasarkan penelitian-penelitian yang relevan, turut memperkuat kajian dalam penelitian ini, seperti penelitian yang dilakukan oleh Penelitian Fitria (2019) melalui judul penelitiannya, "Manajemen Sarana Prasarana dalam Meningkatkan Proses Pembelajaran." Hasil penelitiannya menunjukkan bahwa 14 item belum memenuhi standar yang terdapat pada Permen Nomor 24 Tahun 2007, sarana prasarana yang belum memenuhi standar yaitu: Ruang kelas, ruang perpustakaan, ruang laboratorium biologi, ruang laboratorium fisika, ruang laboratorium kimia, ruang laboratorium komputer, ruang laboratorium bahasa, ruang guru, ruang UKS, ruang organisasi kesiswaan, jamban, gudang, ruang sirkulasi, dan ruang perlengkapan olahraga. Sedangkan sarana prasarana yang sesuai dengan standar yang terdapat pada Permen Nomor 24 Tahun 2007 hanya 4 item yaitu: ruang pimpinan, ruang Tata Usaha, ruang ibadah, dan ruang konseling. Kepala sekolah selaku pimpinan disekolah telah menerapkan fungsi administrasi untuk membenahi sarana prasarana yang ada disekolah dimulai dari fungsi perencanaan, pengkoordinasian, penyaluran, sampai dengan 
pertanggungjawaban, dengan menetapkan fungsi tersebut diharapkan dapat mengoptimalkan sarana prasarana dalam meningkatkan proses pembelajaram di SMA Negeri 9 Palembang. . Dari penelitian relevan ini dapat peneliti simpulkan bahwa ada persamaan dan perbedaan penelitian tersebut dengan penelitian sekarang yaitu sama-sama meneliti tentang manajemen guru dalam proses pembelajaran, selanjutnya perbedaan yang terdapat dalam penelitian ini dengan penelitian sekarang adalah tempat penelitian dan kajian subjek yang menjadi fokus penelitian.

Penelitian Arafat (2020) dengan judul, "Pengaruh Supervisi Akademik dan Kompetensi Profesional Guru terhadap Kinerja Guru di Sekolah Menengah Atas Negeri di Kecamatan Tanjung Raja". Kesimpulan dari penelitian ini adalah : Berdasarkan hasil penelitian dan pembahasan yang telah dilakukan sebelumnya baik melalui analisis statistik deskriptif maupun analisis statistik inferensial, serta temuan-temuan dalam penelitian ini dapat disimpulkan bahwa pertama, terdapat pengaruh yang signifikan supervisi akadedemik terhadap kinerja guru Sekolan Menengah Atas Negeri di Kecamatan Tanjung Raja. Kedua, terdapat pengaruh yang signifikan kompetensi profesional guru terhadap kinerja guru Sekolah Menengah Atas Negeri di Kecamatan Tanjung Raja. Ketiga, terdapat pengaruh yang signifikan supervisi akademik dan kompetensi profesional guru secara bersama-sama terhadap kinerja guru Sekolah Menengah Atas Negeri di Kecamatan Tanjung Raja. Dari penelitian relevan ini dapat peneliti simpulkan bahwa ada persamaan dan perbedaan penelitian tersebut dengan penelitian sekarang yaitu sama-sama meneliti guru yang profesional dalam proses pembelajaran, selanjutnya perbedaan yang terdapat dalam penelitian ini dengan penelitian sekarang adalah tempat penelitian dan kajian subjek yang menjadi fokus penelitian.

Penelitian Destiniar (2020) dengan judul, " Pengaruh Profesionalisme Guru dan Supervisi Kepala Sekolah Terhadap Kinerja Guru". Hasil penelitian ini menyimpulkan bahwa: 1) Terdapat pengaruh profesionalisme guru terhadap kinerja guru SMP Negeri Sub Rayon 16 Kecamatan Sukarami Kota Palembang. 2) Terdapat pengaruh Supervisi Kepala Sekolah terhadap Kinerja Guru SMP Negeri Sub Rayon 16 Kecamatan Sukarami Kota Palembang. 3). Terdapat Pengaruh Profesionalisme guru dan Supervisi Kepala Sekolah terhadap kinerja Guru SMP Negeri Sub Rayon 16 Kecamatan Sukarami Kota Palembang. Dari penelitian relevan ini dapat peneliti simpulkan bahwa ada persamaan dan perbedaan penelitian tersebut dengan penelitian sekarang yaitu sama-sama meneliti profesionalisme guru dalam proses pembelajaran, selanjutnya perbedaan yang terdapat dalam penelitian ini 
dengan penelitian sekarang adalah tempat penelitian dan kajian subjek yang menjadi fokus penelitian.

Penelitian Lian (2020) dengan judul, "Strategi Kepala Sekolah dalam Mengembangkan Kompetensi Profesional Guru.” Hasil penelitian ini menyimpulkan bahwa strategi kepala sekolah dalam mengembangan kompetendi profesional adalah guru ditugaskan untuk mengikuti pendidikan \& latihan, baik yg dilakukan lembaga sekolah itu sendiri maupun oleh lembaga pendidikan lain. Kemudian guru diminta melatih dan mengembangkan dirinya yang berhubungan dengan pekerjaan atau jabatannya seperti kedisiplinan, diskusi dan memberi motivasi. Selain itu kepala sekolah juga melengkapi sarana prasarana sekolah. Dari penelitian relevan ini dapat peneliti simpulkan bahwa ada persamaan dan perbedaan penelitian tersebut dengan penelitian sekarang yaitu sama-sama meneliti profesionalisme guru dalam proses pembelajaran, selanjutnya perbedaan yang terdapat dalam penelitian ini dengan penelitian sekarang adalah tempat penelitian dan kajian subjek yang menjadi fokus penelitian.

Penelitian Harapan (2020), dengan judul, "Pengaruh Profesionalisme Guru dan Supervisi Kepala Sekolah Terhadap Kinerja Guru." Hasil penelitian ini menyimpulkan bahwa: (1) terdapat pengaruh yang signifikan profesionalisme guru terhadap kinerja guru; (2) terdapat pengaruh yang signifikan supervisi kepala sekolah terhadap kinerja guru; dan (3) terdapat pengaruh yang signifikan profesionalisme guru dan supervisi kepala sekolah secara bersama terhadap kinerja guru. Dari penelitian relevan ini dapat peneliti simpulkan bahwa ada persamaan dan perbedaan penelitian tersebut dengan penelitian sekarang yaitu samasama meneliti profesionalisme guru dalam proses pembelajaran, selanjutnya perbedaan yang terdapat dalam penelitian ini dengan penelitian sekarang adalah tempat penelitian dan kajian subjek yang menjadi fokus penelitian.

\section{SIMPULAN}

Berdasarkan hasil penelitian mengenai manajemen guru mengajar dalam memperbaiki mutu pembelajaran di SMA Negeri 4 Prabumulih, disimpulkan bahwa manajemen guru dalam mengajar dapat dikatakan baik. Guru dalam mengevaluasi hasil pembelajaran dapat dikatakan baik, karena evaluasi yang dilakukan setiap akhir dari proses pembelajaran baik tengah semester maupun per semester (semester ganjil dan semester genap), guru dalam memberikan tindaklanjut/follow up dapat dikatakan baik, dan guru dalam memberikan penguatan terhadap peserta didik dalam proses pembelajaran dapat dikatakan baik. Kendala yang dihadapi guru mengajar keterbatasannya sarana prasarana yang ada di SMA Negeri 4 
Prabumulih yaitu infocus, buku pegangan guru dan buku pegangan siswa, alat peraga sebagai media pembelajaran, kemampuan guru dalam penggunaan I.T (khususnya guru dalam menggunakan infocus), keterbatasan kemampuan guru dalam menggunakan media (guru kurang mampu dalam menyesuaikan media dengan pembelajaran yang disampaikan). Strategi yang dilakukan dalam memperbaiki mutu pembelajaran yaitu menggunakan buku elektronik dalam menyampaikan pembelajaran; guru-guru menerapkan literasi digital sebagai pengganti terbatasnya sarana yang ada seperti infocus, buku pegangan guru, alat peraga sebagai media pembelajaran, guru dalam menyampaikan materi pembelajaran memvariasikan metodemetode pembelajaran yang ada, sehingga dapat terciptanya suasana belajar yang aktif, kreatif dan menyenangkan.

\section{REFERENSI}

Arafat, Y. 2020. Pengaruh Supervisi Akademik dan Kompetensi Profesional Guru terhadap Kinerja Guru di Sekolah Menengah Atas Negeri di Kecamatan Tanjung Raja. Jurnal Manajemen Pendidikan. Volume 9, Nomor 1, Juni 2020. Halaman 104-114

Destiniar. 2020. Pengaruh Profesionalisme Guru dan Supervisi Kepala Sekolah Terhadap Kinerja Guru. Jurnal Manajemen Pendidikan, Volume 5 Nomor 2,Juli - Desember 2020. Halaman 168-174.

Djamarah, S. B. 2014. Guru dan Anak Didik Dalam Interaksi Edukatif. Jakarta: Rineka Cipta.

Hamid. 2010. Implementasi Guru dalam Proses Belajar-Mengajar. Jakarta: Raja Graffindo Persada.

Harapan, E. 2020. Pengaruh Profesionalisme Guru dan Supervisi Kepala Sekolah Terhadap Kinerja Guru. Jurnal Manajemen, Kepemimpinan, dan Supervisi Pendidikan, Volume 5 Nomor 2, Juli 2020. Halaman: 168-174.

Karawati, E. 2014. Manajemen Kelas. Bandung: Alfabeta.

Kurniasih, I. 2017. Kompetensi Pedagogik, Teori dan Praktik Untuk Peningkatan Kinerja dan Kualitas Guru. Jakarta: Kata Pena.

Lian, B. 2020. Strategi Kepala Sekolah dalam Mengembangkan Kompetensi Profesional Guru. Jurnal Superivis, Pemimpin dan Manajemen Pendidikan, Volume 4 Nomor 3 Tahun 2020. Halaman 1836-1839. SSN: 2614-6754 (print) ISSN: 2614-3097(online).

Nurdin, S. 2014. Guru Profesional dan Implementasi Kurikulum. Jakarta: Ciputat Pers.

Rizaldi, A. 2014. Dari guru Konvensional Menjadi Guru Profesional. Jakarta: Grasindo.

Rusman. 2011. Guru dan Profesinya. Jakarta: Rineka Cipta

Sukardi. 2016. Guru Powerfull, Kunci Sukses Menjadi Guru Efektif. Bandung: Kolbu

Sumardin. 2016. Pengembangan Profesionalisme Guru Berbasis MGMP Model dan Implementasinya. Yogyakarta: Budi Utama 
Susanto, A. 2016. Teori Belajar dan pembelajaran di Sekolah Dasar. Jakarta: Prenada Media Grup

Usman, Moch, Uzer. 2011. Menjadi Guru Profesional. Bandung: Remaja Rosdakarya

Wahyuningrum. 2013. Pengelolaan Kelas di Sekolah Dasar. Bandung: Alfabeta.

Wasliman, Iim. 2012. Problemantika Pendidikan Dasar dan Menengah. Bandung: Universitas Pendidikan Indonesia 